\title{
COMMERCIAL EXPRESSION COMES OF AGE: THE PATH TO CONSTITUTIONAL RECOGNITION UNDER THE CHARTER OF RIGHTS*
}

\author{
MICHAEL J. TILLEARD**
}

The author assesses developments in the treatment given to claims for the constitutional protection of commercial expression, both under the U.S. Bill of Rights and the Charter of Rights. He questions the traditional notion that forms of expression warrant protection in accordance with their "worth" or "hardiness". Recent Supreme Court of Canada decisions on commercial expression are analysed and the findings viewed in relation to the recent constitutional challenge to the ban on advertising of tobacco products.
L'auteur évalue comment ont été traitées les demandes invoquant la protection constitutionnelle de la liberté d'expression commerciale, aux termes $d u$ US Bill of Rights et de la Charte des droits et libertés. Il remet en question la notion traditionnelle voulant que les formes d'expression méritent protection en fonction de leur "valeur" ou "temps d'utilisation durable" [hardiness]. Les décisions récentes de la Cour suprême du Canada en matière d'expression commerciale sont analysées et les conclusions sont examinées par rapport à la récente contestation concernant l'interdiction de la publicité sur les cigarettes.

TABLE OF CONTENTS

I. INTRODUCTION ......................... 604

II. THE "CATEGORY APPROACH" TO

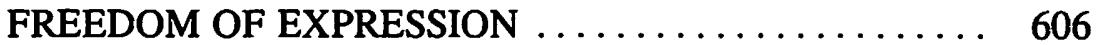

III. U.S. CASE LAW ....................... 609

A. EARLY DEVELOPMENTS:

THE GRANTING OF LIMITED PROTECTION

TO COMMERCIAL SPEECH . . . . . . . . . . . 609

B. THE INFLUENCE OF EARLIER

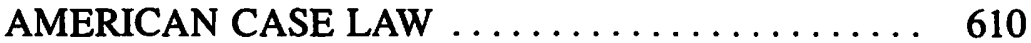

C. RECENT DEVELOPMENTS IN U.S. CASE LAW . . . . 613

IV. COMMERCIAL EXPRESSION AND THE

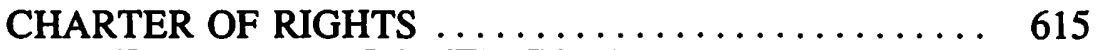

A. APPELLATE AND LOWER COURT DECISIONS . . . . 615

B. THE SUPREME COURT DECISIONS IN

FORD AND IRWIN TOY .................. 620

1. Ford v. Quebec (Attorney General) ............ 620

2. Irwin Toy Ltd. v. Quebec (Attorney General) ........ 621

V. TOBACCO ADVERTISING AND THE CHARTER ...... 626

VI. CONCLUSION $\ldots \ldots \ldots \ldots \ldots \ldots \ldots \ldots \ldots \ldots \ldots \ldots$

\section{INTRODUCTION}

The Supreme Court of Canada has handed down two decisions in recent months, Ford v. Quebec (Attorney General)' and Irwin Toy Ltd. v. Quebec

* This article was a prize-winning entry in the 1990 William Morrow Essay Contest.

** Student-at-Law with the firm of Field and Field, Edmonton.

I. [1988] 2 S.C.R. 712. 
(Attorney General), ${ }^{2}$ that finally establish that "commercial expression"', or the advertising of goods and services to the public, is entitled to constitutional protection under section 2(b) of the Canadian Charter of Rights and Freedoms. ${ }^{3}$ Section 2(b) gives everyone freedom of thought, belief, opinion and expression, including freedom of the press and other media of communication.

In the Ford case, the Supreme Court struck down a Quebec law requiring that public signs and commercial advertising be in French only. In deciding this question, the court was obliged to decide whether the fact that such signs have a commercial purpose removed this form of expression from the scope of protected freedom. The court unanimously agreed that there was "no sound basis on which commercial expression can be excluded from the protection of section 2(b) of the Charter." 4

The Court in Ford, however, was not required to deal with the reasonableness of limits on commercial expression pursuant to section 1 of the Charter, a task which was left to Dickson C.J. and Beetz, Lamer, Wilson and McIntyre J.J. in the April 1989 decision in the Irwin Toy case. This decision is important not only for its definitive treatment of the issue of constitutional protection for commercial expression, but also because the court sets out clear guidelines on the correct analysis to be followed in dealing with freedom of expression cases under section 2(b). In this case, although unanimously confirming that commercial free speech is protected by section 2(b) and agreeing that Irwin Toy's right to advertise had been violated, a 3-2 majority nevertheless disagreed with the majority in the appellate court and upheld, under section 1 of the Charter, a Quebec law which specifically prohibited commercial advertising on television directed at persons under 13 years of age. ${ }^{5}$ The decision is significant since the manner in which the Supreme Court reached its decision will most likely affect a number of freedom of expression cases, for example those involving prostitution, hate propaganda, advertising by the professions, and tobacco advertising restrictions.

In this article, I would first like to make some observations on the issue of whether or not there is a distinct and separate category of free speech called "commercial expression". This will be followed by an assessment of developments in the case law in both the United States and Canada on commercial expression, as well as more detailed comment on the Ford and Irwin Toy decisions. Finally, I propose to review the constitutional challenge currently being undertaken by some tobacco manufacturers to the Tobacco Products Control Act,${ }^{6}$ which prohibits the advertising and promotion of tobacco products, and assess whether this legislation can withstand Charter scrutiny.

2. (1989), 58 D.L.R. (4th) 577.

3. Canadian Charter of Rights and Freedoms, Part I of the Constitution, Act 1982, being Schedule B of the Canada Act 1982 (U.K.), 1982 c.11

4. Supra, note 1 at 767.

5. Consumer Protection Act, R.S.Q., c.P-40.1, previously S.Q. 1978, c.6, ss.248, 249.

6. Tobacco Products Control Act, 1988, S.C. 1986-87-88, c.51. 


\section{THE “CATEGORY APPROACH” TO FREEDOM OF EXPRESSION}

Prior to these recent Supreme Court decisions, the appellate and lower courts in Canada have responded in differing ways to challenges to legislation which have restricted an individual's or a corporation's right to advertise or solicit business. It is my contention that the hesitancy shown by the courts towards granting fully-fledged constitutional protection to commercial expression stems largely from their being over-influenced by American jurisprudence on the commercial speech issue, and the related underlying philosophical theories as to when certain kinds of speech qualify for protection under the First Amendment of the American Bill of Rights. The First Amendment states that "Congress shall make no law. . . abridging the freedom of speech."

In particular, I would submit that the approach taken by some courts, and by some academic commentators, of attempting to establish a hierarchy of protected forms of expression, in accordance with how each measures up to a certain standard of worthiness or moral value, is one fraught with inconsistencies and ultimately highly unsatisfactory. I suggest that the Supreme Court in Irwin Toy also recognized the weaknesses inherent in the "category approach" by giving a very wide interpretation to the spheres of activity protected under section 2(b), prior to determining whether any restrictions on such activity are demonstrably justified in a free and democratic society (the section 1 analysis). The Court held that it is necessary to determine initially whether a particular activity conveys a meaning, and hence has expressive content. If so, the activity prima facie falls within the scope of the guarantee. The Court explains the function of section 2(b) of the Charter without embarking on any analysis of the moral worth of an activity or its appropriate place in a hierarchy of categories of expression: ${ }^{8}$

Freedom of expression was entrenched in our Constitution and is guaranteed in the Quebec

Charter so as to ensure that everyone can manifest their thoughts, opinions, beliefs, indeed all expressions of the heart and mind, however unpopular, distasteful or contrary to the mainstream (my emphasis).

Earlier commentators on the Canadian Charter have propounded their own theories as to where different forms of speech fall in the hierarchy under section 2(b). Finkelstein, ${ }^{9}$ for example, regards social utility as the determinant of where different forms of speech fall in the Charter hierarchy. Political speech can be found at the top of the hierarchy, because a democracy cannot function without it, while commercial speech falls somewhere in the middle because its informational component has some social utility; obscenity is at the bottom of the scale because it is considered to be without social value. ${ }^{10}$

American commentators have conducted more thorough analyses, however, into what constitutes the appropriate values and principles underlying constitutionally protected free speech. Three major theories arising from the work of

7. Amendments to the Constitution of the United States, 1789, Article 1.

8. Supra, note 2 at 606.

9. N. Finkelstein, "'Section 1: The Standard for Assessing Restrictive Govemment Actions and the Charter's Code of Procedure and Evidence" (1983) 9 Queens L.J. 143.

10. Ibid. at 169. 
American scholars are identified by Professor Sharpe in his article on "Commercial Expression and the Charter". "These are:12

1. Freedom of expression is essential to intelligent and democratic selfgovernment.

2. Freedom of expression protects an open exchange of views, thereby creating a competitive market-place of ideas which will enhance the search for truth.

3. Freedom of expression is an aspect of individual autonomy and is to be protected because it is essential to personal growth and self-realization.

Although Sharpe holds that commercial speech is not deserving of constitutional recognition under the first theory, since the "banter of the marketplace" is hardly the equivalent of political debate, ${ }^{13}$ he does concede that a case can be made for giving protection to commercial speech under the second and third theories. However, this concession is made because the interests of listeners are at stake, not the speakers, who simply "seek profit, not truth or selfexpression". ${ }^{14}$ Under the market-place of ideas theory, commercial speech is protected because "advertising provides consumers with information needed to assess the truth about available products and their prices" $;{ }^{15}$ while under the individual autonomy theory, advertising, because it shapes the attitudes, tastes and preferences of listeners, is deserving of a limited form of protection.

Sharpe supports the traditional view of imposing an hierarchical structure on categories of expression by maintaining that commercial speech should be accorded "a level of constitutional protection significantly lower than that appropriate for other forms of expression". ${ }^{16}$ Under the market-place of ideas theory, for example, he asserts that "truth about goods and services is less elusive than political or artistic truth, and that makes the case for the regulation of commercial speech stronger".${ }^{17}$ I suggest the truth of this statement itself is somewhat elusive since it is something of an over-simplification. In many respects, political statements have similarities to commercial speech, just as they have differences. Both a politician's campaign promises to improve an elector's standard of living if she receives the elector's vote, and an advertiser's promises to improve a consumer's material or psychological well-being, are all statements containing a large measure of "puffery", and the public has come to recognize them as such. ${ }^{18}$ The truth of each is elusive to some degree. However, it is doubtful, I suggest, whether we can accurately identify and measure the constituent elements of truth and puffery in either set of promises to the extent that two categories of expression are delineated, with one clearly subject to greater regulatory control than the other.

11. R.J. Sharpe, "Commercial Expression and the Charter" (1987) 37 U.T.L.J. 229.

12. lbid. at 232.

13. Ibid. at 233.

14. Ibid. at 258-9.

15. Ibid. at 235 .

16. Ibid. at 259.

17. Ibid. at 235 .

18. For further discussion of this point, see: D.E. Lively, "The Supreme Court and Commercial Speech: New Words with an Old Message" (1987) 72 Minn. L. Rev. 289. 
Further, if a politician, or other individual, embarked on a campaign of making what appeared to be false and malicious statements about other individuals, then such persons could seek protection from the law of libel and slander and claim appropriate damages (the accepted test being whether such words lower the persons in the estimation of right-thinking members of society generally). Similarly, if a manufacturer or retailer embarks on an advertising campaign which appears to mislead consumers, then these consumers can obtain redress under provincial or federal misleading advertising legislation (the test being, for example, whether the advertiser's representations have "the effect or might reasonably have the effect of deceiving or misleading a consumer or potential consumer' 19 ). In either case, regulation is required to place limitations on false or misleading speech which causes harm to its listeners or subjects, regardless of how one wishes to categorize that speech. As D.E. Lively has noted:20

Because categories of expression are often intertwined, the line drawing process invites procrustean efforts to force multidimensional speech into one arbitrary category. Such a process results in insensitive distinctions and a diminished status for complex expression.

As an example, the author cites a case ${ }^{21}$ where the court was asked to classify an investment newsletter which addressed commercial, political, social and economic matters. ${ }^{22}$

Fortunately commentaries are emerging, along with judicial decisions, which are not preoccupied with categorizing speech forms, but which recognize the multi-faceted character of most speech and are prepared to grant prima facie constitutional protection to all forms of expression. Such a view is held by Professor Stephen Scott, who has reviewed some of the issues and the case law on commercial expression in his submissions in June 1988 to the Senate Committee considering the constitutionality of Bill C-51, the Tobacco Products Control Act ${ }^{23}$ Scott maintains that since the constitutional guarantee found in section 2(b) is expressed in "absolutely general terms", and "since the burden of establishing the contrary rests on those who assert the contrary, the guarantees of section 2 prima facie protect all 'thought', all 'belief', all 'opinion', and all 'expression'." 24 In other words, section 1 scrutiny is available to allow those who have this burden to show that legislative restraints on these guarantees are legitimate and demonstrably justified. It is also Professor Scott's position, and one to which I subscribe, that there is no justification for "carving out" spheres of expression, like "commercial" expression, from the guarantee of section 2(b) of the Charter, and leaving such spheres without constitutional protection, "regardless of circumstances" (his emphasis) ${ }^{25}$ I will argue later that the Supreme Court in Irwin Toy has adopted a position on

19. See Unfair Trade Practices Act, R.S.A. 1980, c. U-3, s.4(1)(d).

20. Supra, note 18 at 296.

21. Ibid. at 296, n. 43 (Lowe v. S.E.C. (1985), 472 U.S. 185.).

22. The classification issue was not decided.

23. S.A. Scott, "Tobacco Advertising and the Canadian Constitution." Brief respecting Bill C-51, the Tobacco Products Control Bill, June 20, 1988. Unpublished manuscript provided by the author.

24. Ibid. at 54 .

25. Ibid. at 55 . 
commercial expression which is much closer to Professor Scott's than it is to Professor Sharpe's.

Also, in a reply to Sharpe's paper, ${ }^{26}$ Professor Henry Manne is quite critical of Sharpe's thesis, holding that Sharpe is "misinformed about both the nature of American constitutional development and the underlying economic realities in the area of commercial speech." ${ }^{27}$ Warning that "American constitutional doctrine is a slippery slope for Canadian courts or commentators to climb" ${ }^{28}$ Manne's view is that government regulation of commercial speech has nothing to do with consumer protection but is simply the result of the influence of significant private economic interests. He concludes: ${ }^{29}$

It is simply diny, self-serving politics as usual. And to raise discussions about the desirability of these regulations to the rarified atmosphere of whether the speech prohibited is constitutionally worthy is, if you will pardon the expression, balderdash.

\section{U.S. CASE LAW}

\section{A. EARLY DEVELOPMENTS: THE GRANTING OF LIMITED PROTECTION TO COMMERCIAL SPEECH}

The traditional view in American jurisprudence and academic commentary was that freedom of speech under the First Amendment applied solely to political expression..$^{30}$ As for commercial speech, the courts followed, for over thirty years, the 1942 U.S. Supreme Court decision in Valentine v. Chrestenson $^{31}$ and refused to recognize that such speech was worthy of protection. In this case a city ordinance prohibiting distribution of commercial or business advertising materials was upheld, as advertising was regarded as simply the pursuit of "gainful occupation" and should not be treated as speech at all. ${ }^{32}$

It was not until 1976 that the U.S. Supreme Court, in the Virginia State Board of Pharmacy case ${ }^{33}$ held that commercial speech was entitled to some constitutional protection. The issue before the court was whether a pharmacist's right to advertise the price of prescription drugs was protected under the First Amendment. The court was able to stay true to its obligation to link drug price advertising to the world of political discourse by saying that, while not clearly giving protection to the advertiser's (or speaker's) interest, it was important for the consumer (or listener) to be provided with a free flow of commercial information, which in itself satisfied the rationale of the First Amendment: that is to "enlighten public decision-making in a democracy." 34

26. H.G. Manne, "The Inversion of Constitutionalism" (1987) 37 U.T.L.J. 280.

27. lbid. at 262.

28. Jbid. at 265.

29. lbid. at 267.

30. A. Meiklejohn, Free speech and its relation to self-govermment (1948); and R. Bork, "Neutral Principles and Some First Amendment Problems" (1971) Indiana L.J. I.

31. 316 U.S. 52 (1942).

32. Ibid. at 54 .

33. Virginia State Board of Pharmacy v. Virginia Citizen's Consumer Council 425 U.S. 748 (1976).

34. Ibid. at 756. 
The cases that follow Virginia Pharmacy continue to be indicative of the U.S. Supreme Court's reluctance to provide unqualified protection to commercial advertising. Because the speaker's interest in advertising is purely economic, and hence unworthy of protection, while the listener's interests are worthy of protection, since the information received leads to life-affecting economic decisions ${ }^{35}$ (which in turn promote self-development and selfdetermination), the overall status given to commercial speech within the scheme of the First Amendment can never reach the "Triple A" rating, as it were, accorded to political or artistic expression.

In the 1977 case of Linmark Associates ${ }^{36}$ the court considered a city by-law that prohibited people from putting "For Sale" signs on their lawns. The purpose of the by-law was to deter the white population from hastily selling their homes in an area into which black people were moving. The Court struck down the by-law as being contrary to the First Amendment largely because the listener's right to receive information had been infringed. Such information deserved protection because it tells the listeners something about the important issue of "where to live and raise their families." "37

In 1977, in Bates v. State Bar of Arizona ${ }^{38}$ the Court dealt with the rights of lawyers to advertise fees for their services and, following Virginia Pharmacy, found the ban unconstitutional on the ground that it set up a paternalistic barrier to the free flow of information. ${ }^{39}$ A year later, however, in Ohralik v. Ohio State Bar Association, ${ }^{40}$ the Court upheld a ban on in-person solicitation of personal injury claims by lawyers (the "ambulance chasing" approach), but again the Court based its judgment on the principle that commercial speech occupies a "subordinate position in the scale of first amendment values," 41 without really justifying that that was in fact the case.

\section{B. THE INFLUENCE OF EARLIER AMERICAN CASE LAW}

The reasoning in earlier American case law seems to have had a strong influence on the thinking of some Canadian courts and Canadian commentators when dealing with the issue of commercial expression under section 2(b) of the Charter of Rights. ${ }^{42}$

35. Ibid. at 763-4.

36. Linmark Associates Inc. v. Township of Willingboro 432 U.S. 85 (1977).

37. Ibid. at 96.

38. 433 U.S. 350 (1977).

39. See also Re R.M.J. 102 S. Ct. 929 (1982), where the Supreme Court struck down certain restrictions on lawyer advertising.

40. 436 U.S. 447 (1978).

41. Ibid. at 455 .

42. It is recognized that pre-Charer Canadian jurisprudence focused on free speech in a political context (see, for example, the Alberia Press case (Re Alta. Statules, [1938] S.C.R. 100); or Switzman v. Elbling, [1957] S.C.R. 285) and these must have exerted some influence on early Charter decisions. However, little consideration was given to commercial expression prior to the Charter, the principal exception being A. G. Canada v. Law Society of British Columbia (1982), 137 D.L.R. (3d) I (S.C.C.), where Mr. Justice Estey, holding that freedom of commercial expression had nothing to do with the elective process and the operation of democratic institutions, dismissed a lawyer's claim that Law Society rules prohibiting advertising violated his freedom of expression. 
For example, Mr. Justice Callaghan speaking for the majority in $R e$ Klein, ${ }^{43}$ approached the issue of defining section 2(b) in much the same way as the U.S. courts, prior to the Virginia Pharmacy decision, approached the task of giving substantive definition to the meaning of the First Amendment. In assessing whether lawyers have a constitutionally protected right to advertise their services, Callaghan J. was content to take the words "freedom of expression" and apply to them the traditional definition under the First Amendment, which is that "freedom of speech" applies only to political discourse and to debate about the functions of political democracy. He states: ${ }^{44}$

Information about the price at which a seller will sell his goods, and the decisions to purchase these goods that are made on the basis of this information have absolutely nothing to say about, and no impact on, political discourse.

The learned judge considered American jurisprudence since Virginia Pharmacy but concluded that, since the American Supreme Court has deemed commercial speech to be quite different from non-commercial speech and entitled to less protection, then " why protect it at all?" 45 What Mr. Justice Callaghan failed to realize, but which was recognized by the dissenting judgment of Mr. Justice Henry in Re Klein, was that there was really no need to embark on a substantive definitional analysis of section 2(b) since, unlike the U.S. First Amendment, he had a section 1 analysis at his disposal. He lost sight of the real issue, therefore, which was to determine what limits on fee advertising by the legal profession, prescribed by law, could be viewed as reasonable and demonstrably justified in a free and democratic society. ${ }^{46}$

One reason found in the American cases for keeping commercial speech lower down the scale of First Amendment values is because it is "hardier" and more "robust" than other forms of expression and can stand up better to the "chilling" effects of regulation. Professor Sharpe endorses this approach and agrees with the court in Bates $^{47}$ that "truth in the case of advertising is more readily ascertainable than in the case of other forms of expression and restrictions aimed at false, deceptive and misleading advertising could be upheld" whereas " a law which forbade fake, deceptive or misleading statements on public affairs would immediately be seen as a tool of tyranny." 48

It is not, I submit, that the truth in the case of advertising is any more ascertainable than the truth of statements about public affairs; it is rather that the harm to consumers resulting from advertising which is clearly false or misleading (and not just "puffery"), is generally more identifiable and quantifiable, and hence subject to more exact control, than the harm which results from false or deceptive statements about an issue of political significance.

For example, it can be established through empirical evidence that an automobile has a fuel consumption of only 20 m.p.g., and not 40 m.p.g. as adver-

43. Klein and Dvorak v. Law Society of Upper Canada (1985), 16 D.L.R. (4th) 489 (Ont. Div. Ct.).

44. Ibid. at 540 .

45. Ibid. at 537.

46. A useful analysis of the Re Klein decision appears in: S. Braun. "Should commercial speech be accorded prima facie constitutional recognition under the Canadian Charter of Rights and Freedoms?" (1986) 18 Ottawa L.R. 37.

47. Supra, note 38 .

48. Supra, note 11 at 242 . 
tised; just as it can be empirically established that the Holocaust did in fact take place if someone denies that it did. If the state chose to allocate sufficient resources to identify and quantify the amount of psychological or emotional harm suffered by individuals or groups who were subjected to false statements regarding the Holocaust, just as the state allocates resources to measure the economic harm resulting from false fuel consumption claims, then there would be clearer and more effective restraints on false statements about matters of public interest. In fact, in the Keegstra case, ${ }^{49} \mathrm{Mr}$. Justice Kerans insisted that if the accused had in fact offered any real threat to the target groups, then the Crown "should be able to prove it"

In any event, there are defamation, obscenity and hate propaganda laws in place which restrain a citizen's freedom to make fake, deceptive or offensive statements pertaining to public affairs. ${ }^{51}$ My point is not to undermine the importance or value of freedom of speech as it relates to public affairs (which, incidentally, can encompass numerous and varied forms of human activity and expression), nor to confer on advertising an undeserved status, but to show that, because the state is generally more successful at regulating what we conveniently call "commercial" expression, as opposed to "political" expression, it does not necessarily follow that a speaker's freedom to make statements of a commercial character is accordingly diminished.

Influenced again, it would seem, by the earlier decisions of the U.S. Supreme Court, Professor Sharpe places considerable emphasis on the greater worthiness one can ascribe to the listener's interest, compared with the speaker's interest, in order to justify the differing status of commercial and other forms of expression. The proposition that it is very important for members of society to receive a fairly constant stream of information on which to base "lifeaffecting economic decisions", while at the same time attributing minimal worth to this information as a form of expression, seems to me somewhat illogical. The rationale for this proposition as expressed by one commentator is that "hawking of wares constitutes no expression of the individual personality, " 52 while receiving information about these wares and deciding to purchase one or more of them may "facilitate the self-development and individual growth of the listener." ${ }^{53}$ Surely both the speaker and the listener here are making economic decisions: the speaker's relates to a marketing or selling strategy; while the listener's relates to a purchasing strategy. Both wish to make a "profit"', one by making and the other by saving money (or at least obtaining value for money). To elevate, therefore, the listener's activity to a level where we can say it has important socio-economic and personal goal-

49. R. v. Keegstra (1988), 87 A.R. 177 at 198 (C.A.).

50. Ibid. at 198.

51. Whether such laws are demonstrably justified in a free and democratic society has yet to be determined by the courts, if necessary, on a case by case basis. The constitutionality of the hate propaganda provisions of the Criminal Code will be decided when the Supreme Court considers the appeal of the Attomey General of Alberta against the decision allowing the accused's appeal of his earlier conviction in the Court of Queen's Bench (see R. v. Keegstra (1985), 19 C.C.C. (3d) 254).

52. J. Weinberg, "Constitutional protection of commercial speech" (1982) Columbia L.R. 720 at 744. Quoted by Sharpe, supra, note 11 at 233.

53. Supra, note 11 at 237. 
directed value, while the speaker's activity receives its limited constitutional protection only through the reflected light, as it were, of the listener's activity is, in my view, a strained form of reasoning.

Commercial expression also has close affinities with artistic expression, to the extent that any dividing line between them is difficult to establish. As Mr. Justice Kaufman pointed out in the appellate court decision in Irwin Toy: ${ }^{: 4}$

It is not for the court to accord more prestige to political, artistic or cultural expression, or to find that the scope of one is greater than that of another since the Charter makes no such distinction. Artistic or cultural expression very often has a commercial purpose, for example, films, videos, and records, as do other activities of a purely commercial nature.

In fact, the Pop art movement arose to question existing artificial and arbitrary distinctions between the world of art and the world of commerce, the distinctions which still prevail in some quarters when attempts are made to define section 2(b) guarantees. I suggest that if you wish to make a depiction of a Campbell's soup can, then both Mr. Andy Warhol and the commercial artist employed by the Campbell's Soup Company have an equal right to do so under any constitution which guarantees freedom of expression in very general terms. ${ }^{\text {ss }}$

Also, if one adopts the category-approach, what level of constitutional protection would one give to a television commercial which went on to win an award at the Cannes Film Festival of Commercial Films? Does its winning an award give it greater aesthetic appeal than when it appeared on my television, and hence its increased "worthiness" allows it to claim a place nearer to the top of the hierarchy of forms of protected expression? If so, this means the writers and producers of such pieces begin their activity " at a level of constitutional protection significantly lower than that appropriate for other forms of expression", ${ }^{56}$ but gradually climb the ladder to greater protection once it becomes clear that the advertisement has some artistic merit and that the writers and producers of the commercial were not motivated exclusively by the idea of "hawking of wares". Surely such reasoning was not in the minds of the framers of a Charter of Rights which gives everyone freedom of thought, belief, opinion and expression.

What also of advertisements for child safety seats or crash helmets? Do they become more worthy of protection because the government has mandated through legislation that, in the interests of safety, the items advertised be installed or worn?

\section{RECENT DEVELOPMENTS IN U.S. CASE LAW}

The U.S. Supreme Court's decision in 1980 in Central Hudson Gas and Electric $^{57}$ marks a new approach in the way that Court has viewed the con-

54. Irwin Toy Lid. v. Quebec (Attomey General) (1986), 32 D.L.R. (4th) 641 at 652.

55. As one art critic points out: "The commercial artist or designer who has provided the bulk of 'nature' for the Pop artist is an aesthete too. Like the Pop painter, he converts all styles to his needs, and in illustrating an ad for ice cream he does not forget to shape the chocolate on the sphere of vanilla into a perfect outline of a tear." See H. Rosenburg. The De-definition of Art (1983) at 112.

56. Supra, note 11 at 259.

57. Central Hudson Gas \& Electric Corp. v. Public Services Commission of New York 447 U.S. 557 (1980). 
stitutionality of commercial expression. Because of the energy shortage at the time, the state imposed a ban on advertising of gas and electricity by utility companies.

The most interesting aspect of the case from a Canadian viewpoint is that the U.S. Supreme Court approached the issue by deciding, in effect, that the Central Hudson company had made out a prima facie case of an infringement of its First Amendment rights, which then called for scrutiny by the court of the state's interest in banning the advertising. The court followed a three-part test by asking whether: (a) the state's interest in restricting commercial speech was "substantial"; (b) the regulation directly advances this substantial state interest; and (c) whether the state could use a less restrictive means to satisfy this interest. ${ }^{58}$ The similarity of this test to the test set out by the Supreme Court of Canada in $R$. v. Oakes,${ }^{59}$ for use in an analysis under section 1 of the Charter, should not, of course, go unnoticed.

The court found that the advertising ban satisfied the first two tests but, as has happened with many Charter challenges, it found that the least intrusive means had not been chosen and struck down the ban.

The cases which follow Hudson demonstrate the American Supreme Court's willingness to continue to apply this three-part test to commercial expression issues, with the result being an increasing degree of deference by the court to the judgements of the legislatures, which, in the view of some American commentators, has greatly undermined First Amendment protection of commercial advertising. ${ }^{60}$

For example in Metromedia Inc. v. City of San Diego,${ }^{61}$ there was a challenge to a city ordinance restricting billboard advertising of both a commercial and non-commercial kind. The Supreme Court applied the three part-test in Central Hudson and concluded that there was a substantial government interest because billboards were distracting to drivers and led to motor vehicle accidents; banning them would also remove another urban eye-sore. The ordinance also went no further than necessary to advance this interest. The majority also concluded, but rather unconvincingly, that the ordinance directly served these governmental goals and therefore upheld the ban, at least with respect to commercial messages. This demonstration of deference to the legislative will was nevertheless tempered by a majority decision that the ban on non-commercial advertising was invalid under the First and Fourteenth Amendments.

In the latest U.S. Supreme Court judgment on commercial expression, Posadas de Puerto Rico Associates v. Tourism Co. of Puerto Rico, ${ }^{62}$ the court applied the Central Hudson tests and upheld a statute which banned advertising of casino gambling to residents of Puerto Rico, but which allowed advertising directed to tourists. The court, but only in a 5-4 majority, again refused

58. The test of whether the commercial speech at issue concerned a lawful activity and was not misleading or fraudulent had first to be passed, before the further three tests could be applied.

59. [1986] I S.C.R. 103.

60. See, for example, K.L. Edwards "First amendment values and the constitutional protection of tobacco advertising" (1987) 82 Northwestem Univ. L.R. 145.

61. 453 U.S. 490 (1981).

62. 106 S. Ct. 2968 (1986). 
to question the position of the legislature that the means were no more restrictive than necessary. The majority also reasoned that the legislature's greater power to ban casino gambling altogether also entailed the lesser power to restrict its being advertised.

The reasoning in the case has been criticized, and it may even mark " $a$ final and perhaps deadly blow to first amendment protection of commercial advertising." ${ }_{63}$ The harshness of the criticism of the decision may lead to a further evaluation in another commercial expression case in the future, but what is significant from our point of view is that the judicial analysis used by the U.S. Supreme Court in more recent cases has become very similar to that used by Canadian courts. Instead of submerging itself in political theorizing in an attempt to establish the extent to which commercial expression is worthy of protection, the U.S. Supreme Court has given commercial speech prima facie recognition and then tested it, on a case by case basis, according to a section 1-type analysis (although the Hudson test has probably been applied more deferentially than is the case with the Oakes test). The Supreme Court of Canada in Ford ${ }^{64}$ recognized the similarity between the Hudson test and the Oakes test, and noted that the use of the Hudson test in Posadas " reveals the tension between two values: the value of the free circulation of commercial information and the value of consumer protection against harmful speech." 65

\section{COMMERCIAL EXPRESSION AND THE CHARTER OF RIGHTS}

\section{A. APPELLATE AND LOWER COURT DECISIONS}

A review of the treatment given to the issue of constitutional protection of commercial expression by the lower courts in Canada, prior to the Supreme Court's decisions in Ford and Irwin Toy, ${ }^{66}$ reveals a varied and inconsistent approach. In particular, there has certainly not been a general willingness to subject any and all restrictions on forms of expression to section 1 scrutiny without first hearing a court's evaluation of the scope of section 2(b). ${ }^{67}$

This is not to say that the courts have not progressed in the way they have interpreted section 2(b) of the Charter. In fact, there has, generally speaking, been a more liberal and expansive approach to the interpretation process, and we have come a long way in a relatively short time.

Compare for example the majority view in $\operatorname{Re~Klein}^{68}$ in the Ontario Divisional Court in 1985, with the majority position taken in Rocket v. Royal College

63. Supra, note 60 at $\mathbf{1 6 5 .}$

64. Supra, note 1 .

65. Ibid. at 759.

66. Supra, note 2.

67. But see Re Law Society of Manitoba and Savino (1983), I D.L.R. (4th) 285, where the Manitoba Court of Appeal held that restrictions on lawyer advertising are demonstrably justified limits on freedom of expression, pursuant to section l of the Charter. The court appeared to assume that freedom of commercial expression is protected by section 2(b) of the Charter, though the issue was not discussed in any detail.

68. Supra, note 43 . 
of Dental Surgeons of Ontario ${ }^{69}$ by the Ontario Court of Appeal in April 1988. In Re Klein, Mr. Justice Callaghan regarded the purpose of the freedom of expression as fostering healthy political debate and hence maintained that "commercial speech contributes nothing to democratic government because it says nothing about how people are governed or how they should govern themselves".${ }^{70}$ In contrast, in the Rocket case, Mr. Justice Cory specifically overruled the majority in Re Klein, saying that "the useful information society may obtain from commercial messages is so important and the potential benefits so great that they must come within the protective ambit of section 2(b)."71

In the Rocket case, disciplinary proceedings were taken against two dentists who appeared in a Holiday Inn promotional advertisement, the message being that successful dentists stay in Holiday Inns when they travel on business. Cory J.A. (as he then was) found the dentists' actions 'distasteful, pompous and self-aggrandizing' '72 but having brought the advertisement within the ambit of section 2(b), he could not find that the provincial regulations, which prohibited such actions, impaired "as little as possible the freedom of expression of members of the college and the concomitant right of listeners to receive information." 73 Apart from the Rocket case, four other appellate court decisions involving commercial expression are significant: from Alberta, Grier v. Alberta Optometric Association ${ }^{74}$ (involving the right of optometrists to advertise their services) and $R$. v. Jahelk ${ }^{75}$ (dealing with a prostitute's freedom to communicate with clients under section 2(b) and the constitutionality of section 195.1(1)(c) of the Criminal Code prohibiting such discussion); $R$. v. Skinner ${ }^{76}$ (dealing with the same issue as Jahelka) from Nova Scotia; and, of course, Irwin Toy, ${ }^{77}$ from Quebec. All five decisions have recognized that commercial expression is protected under section 2(b) of the Charter.

In the Grier case, Mr. Justice Kerans, for the court, assumed that a protected freedom does not extend to every conceivable human activity, and analysed freedom of expression according to the guidance set down by Chief Justice Dickson in Big M Drug Mart. ${ }^{78}$ Such an analysis considers the language chosen to articulate the specific right or freedom, the historical origins of the concepts enshrined, and the character and the larger objects of the Charter itself.

69. (1988), 27 O.A.C. 52. Leave to appeal to S.C.C. granted, 66 O.R. (2d) xi.

70. Supra, note 40 at 539.

71. Supra, note 69 at 76 .

72. Ibid. at 82.

73. Ibid. Another recent Ontario case which gave recognition to commercial expression under section 2(b) is Re Institute of Edible Oil Foods and the Queen (1988), 47 D.L.R. (4th) 368 (Ont. H.C.), where Mr. Justice McKinlay found that section 4 of Ontario's Oleomargarine Act violated a margarine producer's freedom under 2(b) to colour his product in a wholesome and appetising colour. However, the restriction was found to be a reasonable limit on this freedom, since the legislative objective of protecting the dairy industry in Ontario was of substantial economic and social importance.

74. (1987), 53 Alta. L.R. 289.

75. (1987), 59 C.R. (3d) 164.

76. (1987), 58 C.R. (3d) 137.

77. Inwin Toy Ldd. v. Quebec (Attomey General) (1986), 32 D.L.R. (4th) 641 (C.A.).

78. R. v. Big M Drug Mart Ld. (1985), 1 S.C.R. 295. 
Having conducted this analysis, Kerans, J. concludes that "the dissemination of product information is a valued activity in our society and is protected expression. " $79 \mathrm{He}$ also maintains that: ${ }^{80}$

... the Charter protects expression at least [his emphasis] when uttered in the context of an activity, that, like the democratic political process itself, is honored as fundamental in the Canadian tradition.

What is interesting is that Mr. Justice Kerans delivered the judgment in Grier on the same day as he rendered the decision in $R$. v. Jahelka ${ }^{81}$ In Jahelka, Justice Kerans says: ${ }^{82}$

For the reasons expressed in Grier . . I am of the view that s.2(b) extends, at the very least [his emphasis again], to protect communication made for the purpose of eaming a livelihood because this activity is of fundamental importance in our society.

In Grier, the learned judge used as examples of activities of fundamental importance the right to marry and raise a family; so to these he is now adding "speech 'for the purposes of marketing one's body' " which, he implies, is no different from the right of a professional athlete to market his or her body. ${ }^{83}$

However, in Grier he has some doubt about offering constitutional protection at the same time "to expressionist art but also to those whose idea of self-realization is to parachute from tall buildings or bray 'yahoo' into the ears of strangers." 84 And, finally, when he says in Jahelka: "I trust it is understood that it is possible to defend the freedom of another to say something without necessarily approving what the person says," ${ }^{85}$ he seems to be at odds with his position in Grier that there are certain limits on freedom of expression when considering its meaning at the definitional stage. After all, some people, such as stunt artists, do earn a livelihood by parachuting from tall buildings, and it is possible to defend the freedom of someone who wishes to shout "yahoo" into the ears of strangers without approving of what he is saying.

Jahelka, I submit, therefore, is a far more satisfactory judgment since the learned judge seems, in spite of what he states in Grier, to imply that prima facie protection can be given to any utterances or conduct, but where they are prohibited by law, such laws must be adequately justified under the section 1 test.

These decisions also include references to the underlying rationales for the protection of freedom of expression, as discussed earlier. ${ }^{86} \mathrm{Mr}$. Justice Kerans recognizes that communication for the purpose of earning a living is of fundamental importance in our society, and to this extent such expression, it would seem, falls under the third rationale of individual autonomy. Professor Sharpe, however, asserts that "rarely can advertising embody individual goals, values, or objectives of the speaker." ${ }^{87}$ If the prostitute, as speaker, can claim the

79. Supra, note 74 at 298.

80. Bbid. at 297.

81. Supra, note 75 .

82. Ibid. at 167.

83. Ibid.

84. Supra, note 74 at 295.

85. Supra, note 75 at 167.

86. See supra, note 12.

87. Supra, note 11 at 236. 
protection of section 2(b) when communicating for the purpose of making a living, thus embodying, in effect, individual objectives in her or his advertising, then why cannot other commercial advertisers claim the same protection as speakers, since their objectives are to make a living from the sale of the advertised product. Just because advertisers might operate as a group, this should not affect their individual rights to constitutional protection, any more than those who collaborate on making a film, playing a symphony, or performing a play.

In the Skinner ${ }^{88}$ case, dealing with the same issue as Jahelka, the majority of the Nova Scotia Court of Appeal was prepared to say that " . . freedom of expression is the right of everyone and is not limited to debate of high principles or policy ... " ${ }^{89}$. However, other courts, such as the Manitoba Court of Appeal in a Reference case on sections 193 and 195.1 of the Criminal Code,$^{90}$ unanimously agreed that soliciting sex for money on a street corner is not an exercise of freedom of expression. After reviewing earlier Supreme Court of Canada decisions and invoking the spirit of Milton and Mill, Huband J. concluded that there is "no historical basis for the contention that carrying on a particular trade falls within the ambit of freedom of expression." "91

Much moral indignation pervades the judgment in the Reference case. For example, Chief Justice Monnin comments:92 "I think that Milton and Mill would have been astounded to hear their disquisitions were being invoked to protect the business of whores and pimps. I confess my own astonishment."

If the learned Chief Justice had consulted Mill's On Liberty, ${ }^{93}$ he may have been reassured that Mr. Mill would probably not be turning in his grave, but would be quite prepared to admit that times and attitudes change. Mr. Justice McIntyre quotes the following from Mill's On Liberty in Dolphin Delivery: ${ }^{94}$

Yet it is as evident in itself . . . that ages are no more infallible than individuals: every age having held many opinions which subsequent ages have deemed not only fake but absurd and it is certain that many opinions now general will be rejected by future ages, as it is that many, once general, are rejected by the present.

The Quebec Court of Appeal in the Irwin Toy cases had no difficulty in holding that the wording of section 2(b) does not limit freedom of expression to certain types of expression and there is no rule of interpretation that would exclude commercial expression from section 2(b). Under a section 1 analysis, the majority went on to strike down the ban on television advertising to children since the ban covered advertising of products which were not harmful, and hence the substantial purpose test was not satisfied. However, Kaufman J.A. still makes reference to what I have argued is a redundant approach to the handling of section 2(b) cases by stating that a limit under section 1 "can be

88. Supra, note 76.

89. Ibid. at 159.

90. Ref. re Criminal Code, ss. 193 and 195.1(1)(c) (1987), 60 C.R. (3d) 216.

91. Ibid. at 266.

92. Ibid. at 227.

93. J.S. Mill, On Liberty, Ed. with an introduction by R.B. McCallum (Originally published 1869; edn., Oxford: Blackwell, 1946.

94. R.W.D.S.U. Local 580 v. Dolphin Delivery Lid., [1986] 2 S.C.R. 573 at 574.

95. Supra, note 77. 
quite reasonable in the case of commercial expression, whereas it would not be in the case of political expression." ${ }^{96}$ However, he does not elaborate on the point.

The occasional judgment still persists which harks back to the school of thought adopted by Mr. Justice Callaghan in Re Klein. ${ }^{97}$ In Griffin v. College of Dental Surgeons of B.C. ${ }^{98}$ a Master in Chambers dismissed an appeal by a dentist who had been charged with unprofessional conduct relating to advertising his dental services in newspapers. Justice Rowles canvassed all the major Canadian cases and some U.S. Supreme Court cases but still came to the conclusion that the "Charter does not protect economic rights per $s e$ "99 and hence commercial advertising, which is a component of economic activity, does not come within the scope of freedom of expression in section 2(b). Rowles J. thought that: ${ }^{100}$

The primary purpose of "freedom of expression" as guaranteed by the Charter must surely be the protection of the integrity of the political process . . . In Canada, the economic realm has been subordinate to the political realm, and that has not been expressly altered by the Charter.

The learned judge may have been surprised at the decision of her own Court of Appeal seven months later (August 1988) in Wilson v. British Columbia (Medical Services Commission) ${ }^{101}$ where the court held that section 7 of the Charter includes the incidental economic right to choose one's occupation and where to pursue it. If this is so, I submit that section 2(b) must surely include the associated right to advertise one's occupation.

The Griffin case also contrasts with the Ontario Court of Appeal's decision in Rocket ${ }^{102}$ on the same issue of the right of dentists to advertise. Mr. Justice Cory in the Rocket case noted what the Master in Griffin had forgotten, that is, the Supreme Court judgment in Dolphin Delivery, ${ }^{103}$ which concluded that picketing is a constitutionally recognized form of expression. Cory, J. A. noted that "picketing is a form of commercialism which has been recognized as a form of expression. If picketing constitutes expression worthy of the protection of s.2(b), so too should the commercial expression contained in an advertisement." 104 In fact it is surprising that the few appellate and lower court decisions on commercial expression decided since Dolphin Delivery have not relied more heavily on its apparent conclusion that any activity which involves an element of expression should receive protection under Section 2(b); subject of course to scrutiny under section 1 .

96. Ibid. at 652 .

97. Supra, note 43.

98. (1988), 2 W.W.R. 60.

99. Ibid. at 73 .

100. Ibid.

101. (1988), 53 D.L.R. (4th) 171.

102. Supra, note 69.

103. Supra, note 94.

104. Supra, note 69 at 81. 


\section{B. THE SUPREME COURT DECISIONS IN FORD AND IRWIN TOY}

\section{Ford v. Quebec (Attorney General) ${ }^{105}$}

Of the two decisions, Ford and Irwin Toy, the Ford judgment is the least useful in its assessment of the issue of Charter protection for commercial expression, not only because the Court had to deal with the more politically controversial issue of whether section 2(b) includes the freedom to express oneself in the language of one's choice, as well as the validity of the override provision, but also because, as stated above, there was no necessity for the Court to assess the reasonableness of any limits on advertising pursuant to section 1 .

The decision is important, however, because the Court asserts at the outset that the approach to be taken under Canadian constitutional law to the issue of commercial expression differs in large measure from that followed by American courts. The Court points out that "commercial expression" does "not have any particular meaning or significance in Canadian constitutional law, unlike the corresponding expression 'commercial speech', which in the United States has been recognized as a particular category of speech entitled to First Amendment protection of a more limited character than that enjoyed by other kinds of speech". ${ }^{106}$ The Court clearly dissociates itself from any "category approach" of the kind I have discussed, pointing out that: ${ }^{107}$

The issue in the appeal is not whether the guarantee of freedom of expression in s.2(b) . . . should be construed as extending to particular categories of expression, giving rise to difficult definitional problems, but whether there is any reason why the guarantee should not extend to a particular kind of expression . . .

The Court does briefly review the American case law but only because such cases were mentioned in argument and have been invoked in other Canadian cases on commercial expression. It also reviews the Canadian case law and notes the reliance placed by the Quebec Superior Court in Ford ${ }^{108}$ on American decisions to conclude that the guarantee of freedom of expression in section 3 of the Quebec Charter extended to commercial expression. The Court also notes that the Quebec Court of Appeal in the case at bar had applied the majority judgement in Irwin Toy ${ }^{109}$ to this issue.

The Court then proceeds to reject categorically the rather tired arguments of the Attorney General of Quebec; for example, that there is no pre-Charter jurisprudence guaranteeing commercial expression; or that extending freedom of expression beyond political, and possibly artistic and cultural expression, would trivialize the freedom; or that extending freedom of expression to commercial advertising would mean protecting an economic right. The learned judge disposed of this last argument by making reference to the Dolphin Delivery case ${ }^{110}$ and noted that picketing was protected under section 2(b) even though it was a form of expression having an economic purpose.

105. Supra, note 1 .

106. Ibid. at 755.

107. Ibid. at 755-756.

108. Ford v. Quebec (Attorney General) (1987), 36 D.L.R. (4th) 374.

109. Supra, note 54.

110. Supra, note 94. 
After noting that earlier pronouncements of the Supreme Court recommend that the rights and freedoms guaranteed in the Charter should be given a large and liberal interpretation, the Court concludes that there is no sound basis on which commercial expression can be excluded from the protection of section 2(b) of the Charter. The Court states:"'

Over and above its intrinsic value as expression, commercial expression which . . . protects listeners as well as speakers plays a significant part in enabling individuals to make informed economic choices, an important aspect of individual self-fulfilment and personal autonomy. (My emphasis)

The emphasised part of this quotation suggests that the Court has laid to rest the argument that commercial expression qualifies for only a limited form of protection under the Charter solely because it is the listener's interests which are at stake, while the speaker, whose only apparent interest is profit, is barred from protection.

That the case is also indicative of the Supreme Court's desire to fashion its judgments on issues such as freedom of expression, using primarily its own interpretation of the plain meaning of the words of the Charter and its own previous decisions on Charter cases, is seen from the Court's comments doubting the direct usefulness of the attempts made to identify the values underlying constitutional protection of freedom of expression. Professor Sharpe's three "rationales" 112 are set out by the Court but, although helpful, such values 113

... tend to be formulated in a philosophical context which fuses the separate questions of whether a particular form or act of expression is within the ambit of the interests protected by the value of freedom of expression and the question whether that form or act of expression, in the final analysis, deserves protection from interference under the structure of the Canadian Charter and the Quebec Charter.

These questions, says the Court, call for two distinct analytical processes, the first being the purposive approach as set out in Hunter v. Southam Inc. ${ }^{114}$ and the second being, of course, the section 1 tests as interpreted in Oakes. ${ }^{115}$

\section{Irwin Toy Ltd. v. Quebec (Attorney General) ${ }^{116}$}

The Supreme Court's decision in Irwin Toy reflects a continuation of this trend to approach Charter issues such as freedom of expression from an independent, uniquely Canadian, standpoint, where American jurisprudential influences play little, or no part at all, in the judgment handed down. The Court is clearly at pains to set down a distinct analytical framework for future freedom of expression cases, which takes into account the two distinct questions and processes referred to by the Supreme Court in Ford.

After noting, however, that Irwin Toy differs from Ford in that a determination is necessary in this case as to whether regulations of advertising aimed at children limit the guarantee of freedom of expression, the majority of Dickson

111. Supra, note 1 at 767.

112. Bbid. at 765 .

113. Ibid. at 765-766.

114. (1984), 2 S.C.R. 145.

115. Supra, note 59.

116. Supra, note 2. 
C.J. and Lamer and Wilson J.J. went on to outline a two-step process for use in determining whether a section 2(b) guarantee has been violated.

STEP 1: Is the plaintiff's activity within the sphere of conduct protected by freedom of expression? ${ }^{117}$

The Court regards any activity as protected providing it conveys, or attempts to convey a meaning, that is, that it has expressive content. Activity with no meaning, such as parking a car (unless done as a form of protest) or activity of a violent nature are not within the protected sphere of conduct. Clearly the activity of advertising directed at children conveys a meaning and hence prima facie it falls within the scope of the guarantee.

STEP 2: Is the purpose or effect of the government action to restrict freedom of expression? ${ }^{18}$

The Court views government action as restricting freedom of expression where the government has aimed to control attempts to convey a meaning either by directly restricting the content of expression or by restricting a form of expression tied to content. For example, a rule against handing out pamphlets is a restriction on a manner of expression and is "tied to content", even if that restriction purports to control litter. On the other hand, a rule against littering is not a restriction "tied to content". Such a rule is designed to control the physical consequences of human activity and its purpose is not to control expression. In the case at bar the Court had no doubt that the purpose of the Quebec Consumer Protection Act ${ }^{119}$ was to restrict both a range of content and forms of expression in the name of protecting children.

The Court went further, however, and explained that, even if the government's purpose was not to restrict expression, the plaintiff can still claim that the effect of the govemment's action was to restrict her expression. To make this claim the plaintiff must show that her activity promotes at least one of the principles underlying freedom of expression, either the pursuit of truth, participation in the community, or individual self-fulfillment and human flourishing. For example, it is not enough that shouting has an expressive element. If a challenge is made to government action to control noise, presuming that action to be neutral as to expression, the plaintiff must show that her aim was to convey a meaning reflective of the underlying principles.

What is refreshing about the Court's analysis, and encouraging for prospective litigants making challenges under section 2(b), is the very wide and liberal interpretation given to the meaning of freedom of expression. Little reference is made to categories of expression ranked in a hierarchy according to their worthiness or hardiness. Absent, in particular, is any distinction between the interests of listeners or speakers as a justification for differentiating forms of expression. From the Irwin Toy decision, it would appear that a myriad of forms of expression are prima facie protected under section 2(b) of the Charter; the Court cites "the written or spoken word, the arts, and even physical gestures or acts" ${ }^{120}$ as examples. If this is so then a good case could be made out that 
parachuting from tall buildings should receive the same prima facie protection as expressionist art. (It may be more difficult to make out a similarly strong case for the activity of shouting 'yahoo' into the ears of strangers.)

Passing the Step 2 test, which is a prerequisite for an analysis under section 1 , also does not appear to be fraught with too many obstacles. It should not be too difficult in most cases to show that the government's purpose was to restrict expression, which is defined widely as restricting attempts to convey a meaning. It also does not appear to be necessary at the "purpose" stage of Step 2 to justify that a meaning relates to the underlying principles. This is only required if there is doubt as to the government's purpose, in which case one has to show that the government's action has the effect of restricting freedom of expression.

However, even though the Court repeats Dickson J.'s words in Big M Drug Mart"121 that "purpose is a function of the intent of those who drafted and enacted the legislation at the time, and not of any shifting variable, " ${ }^{122}$ future plaintiffs may not wish to risk relying entirely on convincing a court that the government's purpose was to pass a law restricting a form of expression. The plaintiff may wish to show, in any event, that the effect of the law was to restrict a meaning, which, in turn is clearly related to one of the three underlying principles. It could be argued, therefore, that this requirement to relate an activity to one of the underlying principles means that the Supreme Court has introduced an element of classification into the task of identifying forms of protected speech such that not every act or gesture will survive the Step 2 test. An element of balancing of competing interests takes place, therefore, prior to the section 1 analysis. However, the introduction of the three "rationales" as the test for demonstrating the restrictive effects of government action appears to be necessary only to deter plaintiffs from bringing actions bordering on the frivolous or the absurd. The Court, in fact, only uses the rather extreme examples of shouting, and restrictions on noise, when discussing the need to demonstrate the restrictive effects of government action.

The Court may not therefore have entirely embraced Professor Scott's position $^{123}$ to the effect that all thought, belief, opinion and expression is entitled to prima facie constitutional protection. However, it is submitted that the combined effect of the Step 1 test and the purpose test laid down in Step 2 have nevertheless granted to section 2(b) of the Charter the potential to catch within its net a number of forms of expression whose claims to constitutional protection have hitherto been uncertain, including, of course, commercial expression. Having passed the Step 1 test and the Step 2 purpose test, the balancing process for the vast majority of future challenges would, therefore, virtually all be done at the section 1 stage.

Although all five Supreme Court judges agreed that commercial expression is protected under section 2(b) and that Irwin Toy's rights had been violated, a majority of Dickson C.J. and Lamer and Wilson J.J. nevertheless concluded 
that the Quebec Consumer Protection Act which restricted these rights was a reasonable limitation under section 1 .

In a lengthy and detailed analysis, the majority followed the tests set down in Oakes to conclude, first, that the government had produced materials to establish that children up to the age of thirteen are manipulated by commercial advertising and that the government's objective of protecting all children in this age group is predicated on a pressing and substantial concern. The Court allowed evidence to be introduced of studies on the effects of advertising on children made subsequent to the enactment of the legislation, in order to show that the original objective remained pressing and substantial.

The Court also found that the advertising ban was rationally connected to the objective, while the evidence adduced supported the conclusion of the legislature that the ban was the minimal impairment consistent with the pressing and substantial goal of protecting children against manipulation. The majority noted that where the government is mediating between competing groups the choice of means often requires assessing conflicting scientific evidence and a balance has to be struck without the benefit of absolute certainty. This situation differs from cases where the government acts as a singular antagonist of an individual whose rights have been infringed (such as those enshrined in sections 7-14 of the Charter). In these cases, since there may be no competing claims, then the courts can be quite certain whether the least instrusive means have been selected. The Court noted that other less intrusive means were available to achieve more modest objectives in this section 2 infringement but: ${ }^{124}$

This Court will not, in the name of minimal impairment, take a restrictive approach to social science evidence and require legislatures to choose the least ambitious means to protect vulnerable groups. There must nevertheless be a sound evidentiary basis for the government's conclusions.

In a strong dissenting judgment, concurred in by Mr. Justice Beetz, Mr. Justice McIntyre agreed essentially with the majority in the appellate court and found that it had not been proved that the welfare of children was at risk as a result of advertising being directed at them. Nor were the means proportional to the objective: a total prohibition of advertising on television aimed at children below an arbitrarily fixed age makes no attempt to achieve proportionality.

Moreover, the learned judge suggested that freedom of expression should not be suppressed except where urgent and compelling reasons exist, and we would do well to remember that "in this century whole societies have been utterly corrupted by the suppression of free expression." 125 Even a small step in that direction should not be lightly taken.

Also of importance in Irwin Toy is the majority's assessment of the "minimal impairment" element of the Oakes test, especially because of its implications for future cases, not only on freedom of expression issues, but also where violations of other fundamental freedoms under section 2 are alleged. The Court makes a distinction between its use of the "least drastic means" test when dealing with competing groups, as opposed to dealing with violations of individual legal rights under sections 7-14. This is largely the result of the increased 
difficulty of determining with any certainty whether rights and freedoms have been impaired as little as possible when dealing with competing claims of groups, compared with a claim of infringement of individual rights. This means in effect that a section 1 analysis of the reasonableness of limitations placed on section 2 "Fundamental Freedoms", whether they concern competing claims over retail business holidays, the rights of trade unions and their members, or controls over tobacco advertising (see next section), will likely entail greater deference to the legislature at the "least intrusive means" stage than would be the case if the court was considering a section 7-14 legal right.

After all, it is often quite easy to identify an alternative means of achieving an objective which is less drastic than the one decided upon by the legislature. But as the Court notes: ${ }^{126}$

\section{If the legislature has made a reasonable assessment as to where the line is most properly drawn [between competing claims] especially if that assessment involves weighing conflicting scien- tific evidence . . . it is not for the court to second guess. That would be to only substitute one estimate for another.}

It would appear, on the face of it, that the majority in Irwin Toy has simply given with one hand and taken away with the other. Having unequivocally granted commercial expression as much constitutional protection as any other traditional forms of expression, the Supreme Court seems to have turned this into a hollow victory for the "speakers" of commercial information. It would seem that in the face of detailed social science evidence defining the harm that ensues from a protected activity, carefully drafted legislation which has as its objective the prevention of such harm and established administrative machinery designed to enforce that legislation, the advertiser is likely to be met with deference by the courts to the wisdom of the legislature. It could even be argued that "commercial" expression in Canada now has a status which, for all intents and purposes, is not unlike that accorded to commercial speech in the United States since the decision in Posadas, ${ }^{127}$ that is, enjoying only minimal constitutional protection.

To this extent the decision in Irwin Toy does raise some concerns with respect to the degree of deference that other courts may be encouraged to show, as a result of the Supreme Court's reasoning in this case. It is recognized that those who advocate the retention of distinctions in the level of review for different forms of speech fear, and perhaps justifiably so, that increasing deference by the courts may lead to an increasing failure to recognize the differences between government intervention to control, say, deceptive marketing practices, and intervention to control political pamphleteering designed to promote causes unsympathetic to that government.

However, I would still maintain that adherence to the traditional "categoryapproach" is not a panacea which will always guarantee at least some form of protection to political speech. Adopting distinctions in the level of review for different forms of speech results, as we have seen, in decisions of the kind made by Callaghan J. in Re Klein ${ }^{128}$ and by Rowles J. in Griffin v. College of Dental 
Surgeons of B.C. ${ }^{129}$ Such decisions may confirm the value of political speech, but they also reflect as much, if not more, deference to the wishes of the legislature as may be found in Irwin Toy, except that the deference in Klein and Griffin is hidden in the guise of refusing to recognize that forms of expression other than political speech may be very worthy of constitutional protection. The majority decision in Irwin Toy may raise some concerns with respect to the degree of deference, but at least the Supreme Court avoided all attempts to give what is in essence "artificial" protection to one form of speech over another. Further, since, as I have attempted to show, what is traditionally called "political" speech may often be made up of an amalgam of social, commercial, economic, legal, as well as political speech, then the question of whether categorization is necessary to maintain a sufficiently high level of protection for "political" speech alone, may in fact be redundant. As D.E. Lively has noted: 130

To minimize the dangers inherent in line drawing and avoid ascribing a singular label to expression that may possess multiple dimensions, the Court should refrain from translating perceived practical difficulties between commercial and political speech into constitutional distinctions.

The Irwin Toy decision, then, is not one where we can say that a "commercial" expression issue was singled out for special treatment in a way which would not be accorded to a claim of a violation of "political" or "artistic" expression. Where social policy is concerned, the freedom being limited may be predominantly political, or commercial, or religious or artistic, or contain elements of these and other groupings. Even though the case raises some concerns as to the degree of deference shown to regulatory interests, Irwin Toy is to be welcomed for, hopefully, sounding the death knell of the category approach, such that any legitimate claim to a violation of a fundamental freedom will be treated on its merits, with reference to pre-conceived notions as to the claim's worth or position in a hierarchy of values kept to a minimum.

\section{TOBACCO ADVERTISING AND THE CHARTER}

Given the decisions in Ford and Irwin Toy, it may be instructive to assess how certain tobacco manufacturers might fare in their recent challenges to the constitutionality of Bill C-51, the Tobacco Products Control Act, ${ }^{131}$ which came into force on January 1, 1989.

Section 4 of the Act provides for a blanket prohibition of all advertising of tobacco products in Canada. The ban includes the use of brand names to sponsor sporting or cultural events. ${ }^{132}$ The ban on billboard displays, however, will not come into effect until January $1,1991 .{ }^{133}$ Actions have been commenced recently in the Federal Court of Canada by Rothmans Benson and Hedges Inc., and, by separate motions, in the Quebec Superior Court by Imperial Tobacco Ltd. and R.J.R.-MacDonald Inc., challenging this prohibition on the grounds

129. Supra, note 98.

130. Supra, note 18 at 309.

131. Supra, note 5.

132. Ibid., s.6.

133. Ibid., s.4(5). 
that the power to legislate in this area lies with the provinces and not the federal government, and because it violates freedom of commercial expression under section 2(b). The Imperial Tobacco/RJR-MacDonald action came to trial in September 1989. ${ }^{134}$

On the issue of the challenge under section 2(b), both the manufacturers and the non-smokers' rights groups will view the decision in Irwin Toy as supportive of their respective cases, the manufacturers because freedom to advertise is now fully protected under the Charter, while those arguing to uphold the legislation will see a close analogy between their case and the outcome of the section 1 analysis in Irwin Toy.

Utilizing the 2-step process set out in Irwin Toy to determine if the tobacco manufacturers rights have been infringed, the plaintiffs will most likely pass the first step, since advertising is intended to convey a meaning and has expressive content. It prima facie falls, therefore, within the scope of the section 2(b) guarantee.

The second step is to ask whether the purpose or effect of the Tobacco Products Control Act is to restrict freedom of expression. The government will probably argue that the purpose of the Act is not to restrict expression but is as set out in section 3 of the Act, which is "to provide a legislative response to a national public health problem of substantial and pressing concern." The particular purposes are then listed, which include the protection of "the health of Canadians" and of "young persons and others, to the extent that is reasonable in a free and democratic society, from inducements to use tobacco products. . . ." However, it would appear that the restriction on advertising is analogous to the rule against the handing out of pamphlets, which was used by the Supreme Court in Irwin Toy as an example to illustrate its definition of "government purpose". Like the rule against pamphlet distribution, which may purport to control litter, the rule against advertising is a restriction on a manner of expression and is "tied to content", even though that restriction purports to protect the health of Canadians. The ban on advertising is not like a rule against littering, which is not a restriction "tied to content".

In any event, the tobacco manufacturers may argue in the alternative that the effect of the ban is to restrict their freedom of expression, with appropriate reference being made to the finding in Ford that commercial expression "plays a significant role in enabling individuals to make informed economic choices, an important aspect of individual self-fulfilment and personal autonomy" 135 (the third of the requisite underlying principles that a plaintiff's action must promote, as set out in Irwin Toy).

Given that the plaintiffs will be successful in their claim that the legislation is an infringement of section 2(b) of the Charter, the courts will proceed to a section 1 analysis as set down in Oakes and elaborated upon in Irwin Toy. It is very likely that the courts will accept the government's contention that the objective of the legislation deals with concerns which are "substantial and pressing", words, in fact, which are used in the "Purpose" section of the legis-

134. At the time of going to press this action was still proceeding. The Rothmans Benson and Hedges action has been adjoumed pending the outcome of the Imperial Tobacco challenge.

135. Supra, note 1 at 767 . 
lation itself. ${ }^{136}$ The "Purpose" section also refers to the "conclusive evidence implicating tobacco use in the incidence of numerous debilitating and fatal diseases" 137 and it is this evidence no doubt which will be brought before the courts to justify the government's concerns.

The next stage, showing that the means adopted to achieve the objective are rationally connected to it and "carefully designed" to achieve it, may be more difficult for the government to prove. This is where the battle of the experts begins, because the government now has to show that there is sufficiently strong evidence to conclude that the advertising of tobacco products does in fact induce people to take up smoking or induce those who smoke already to smoke more. This is perhaps not as simple as producing evidence to show a link between tobacco use and disease.

The tobacco manufacturers argue that tobacco advertising does not increase consumption but really only causes existing smokers to switch brands. They cite instances where other countries have banned tobacco advertising but no fall in consumption followed. Young people take up smoking as the result of family influence and peer pressure, not from inducements by advertising. ${ }^{138}$

The anti-tobacco lobby argues that you cannot show a "smoking gun" on tobacco advertising and tobacco consumption, as in many other areas of endeavour - medical, social research, even in criminal prosecutions where you rely on circumstantial evidence. They, however, cite statistics, sometimes from the same country as the tobacco manufacturers, to show that a ban on advertising has led to a decline in per capita tobacco consumption. ${ }^{139}$ (That each side reaches opposite conclusions as to the effect on consumption of a ban on tobacco advertising in such countries as Iceland and Norway, is indicative of the amount of "conflicting scientific evidence" adduced so far on this issue, a situation which will do little to assist the courts in eventually reaching satisfactory decisions.)

Also, if advertising only caused smokers to switch brands, say anti-smoking groups, then the manufacturers would be financially better off not spending money on advertising at all. They also point out that 200,000 children take up smoking each yer and studies show that advertising is clearly one of the inducements. ${ }^{140}$ The anti-smoking lobby also realizes that, just because advertising affects consumption, this might not in itself justify this legislation if it goes further than necessary, that is, if it is not proportional to the problem. They say the legislation is valid because tobacco is the only product which kills when used exactly as intended and so its promotion should be dealt with more severely. Unlike other products, there is no way to promote a safe use of tobacco. ${ }^{141}$

136. Supra, note 5 at s.3.

137. Ibid. at s.3(a).

138. See Canada, Standing Senate Committee on Social Affairs, Science and Technology, June 21, 22, 23, 1988, particularly submissions of Canadian Tobacco Manufacturers Council, June 22, 1988.

139. D. Sweenor, "A response to Charter of Rights arguments against the Tobacco Products Control Act". Unpublished manuscript provided by author, October 1988.

140. Ibid. at 2.

141. Ibid. at 4 . 
Assuming that on a balance of probabilities, which is the standard of proof in Oakes, that the courts will conclude there is a rational connection between the objective of the law and the means chosen, the final stage in the analysis is whether or not the least intrusive means have been adopted to achieve the stated objective.

The manufacturers will no doubt look to American and Canadian case law prior to Irwin Toy on which to base their argument that since freedom of expression protects the rights of speakers to advertise their goods or services and the rights of listeners to receive such information in order to make informed economic choices, then a total ban on the advertising of a product which can be lawfully sold in Canada is clearly overly broad and hence unconstitutional. The manufacturers will want to emphasize that the Supreme Court in Irwin Toy was at pains to point out that it was not upholding a law which sought a general ban on the advertising of children's products. In fact "commercial advertisements may be directed at the true purchasers - parents or other adults." ${ }^{142}$ To this extent, the decision in Irwin Toy can be distinguished and its conclusions should not be followed. The manufacturers would also say that government objectives would be equally well served by prohibitions on the content of some advertising or by a campaign of counter-advertising on an extensive scale, designed to deter the smoking habit.

In the United States a number of bills aimed at eliminating all promotion of tobacco products have recently been put before Congress. ${ }^{143}$ This has led to commentary in American legal journals on whether such a ban would infringe First Amendment rights. ${ }^{144}$ Opinions differ on the outcome, but in predicting the outcome emphasis is given to the final "least restrictive means" test laid down in Central Hudson. ${ }^{145}$

One commentator's view is that now that the constitutional value of selfdetermination, which informed the courts opinion in Virginia Pharmacy, ${ }^{146}$ has been undermined by the Central Hudson and Posadas ${ }^{147}$ cases in favour of greater deference to the wishes of the legislature, the U.S. Supreme Court will continue to use the "least restrictive means" test "as a tool for selective judicial deference to legislative judgements." 148

The anti-tobacco lobby in Canada will also take heart from the uncharacteristic deference shown by the Supreme Court in Irwin Toy to the judgment of the Federal Parliament. As with the issue of the apparent harmful effects of television advertising on children, the issue of the apparent adverse effects of tobacco advertising is argued, as noted, in an arena of "conflicting scientific

142. Supra, note 2 at 624 .

143. C.A. Binger, "Up in smoke: commercial speech and a tobacco products advertising ban" (1987) 54 Tennessee L.R. 703 at 1. Ms. Binger notes that the American Medical Association sponsored six bills before the 99th Congress (1985-86) all of which died at the end of the session.

144. Ibid.; See also Edwards, supra, note 60; M.L. Miller, "The First Amendment and legislative bans of liquor and cigarette adventisements" (1985) 85 Columbia L.R. 632; D.H. Lowenstein, "Too much puff: persuasion, patemalism and commercial speech" (1988) 56 Cincinnati L.R. 1205.

145. See Edwards, supra, note 60; Binger, supra, note 143.

146. Supra, note 33.

147. Supra, note 62.

148. Supra, note 60 at 173. 
evidence", and it may be the case that lower courts will follow the reasoning of the Supreme Court and not disturb the balance which Parliament has struck between the claims of the two lobbies in this dispute. In other words, the courts may not require that the government choose "the least ambitious means to protect vulnerable groups."

In any event, it appears to be accepted social policy at all levels of government that any measure which is more likely than not to reduce tobacco consumption, especially among young people, should always be supported, including bans on advertising. Well-reasoned constitutional arguments, however, should still be given their full due, such as those of Professor Scott who, in his submissions to the Senate Committee, could not see how the legislation could constitutionally prohibit "an advertisement in the print media, without 'lifestyle' characteristics, simply displaying the product, perhaps with factual information pertaining to health (e.g. tar and nicotine content) and containing a full and fair health warning" (his emphasis). ${ }^{150}$

When the issue does reach the Supreme Court, as both sides expect it will, more detailed studies on the relation between an advertising ban and consumption will no doubt be available; and it will be the weight given to this evidence which will play a large part in determining the outcome of the constitutionality of the Tobacco Products Control Act.

\section{CONCLUSION}

As the matter stands at the moment, commercial expression qualifies for fully-fledged constitutional protection under section 2(b) of the Charter of Rights. The path to recognition has not been without its obstacles, not the least of which has been the influence of earlier American jurisprudence on the commercial speech issue which, in my view, has had the effect of restraining Canadian courts from making what would otherwise have been wider and more liberal interpretations of the meaning of freedom of expression under section 2(b). The Supreme Court's decision in Irwin Toy should, at least, mark the end of further attempts at assessing the eligibility for protection of different forms of expression, according to some arbitrary order of merit, or through some determination of the speech's "robustness". That in itself is, I submit, a positive and worthwhile achievement.

The manner in which the Supreme Court approaches future challenges to legislation restricting advertising of goods and services, however, is unpredictable. Irwin Toy was decided by a majority of only 3-2 and only four of those five judges remain on the Court. Five other judges, therefore, have yet to deliver their views on this issue (at least, at the Supreme Court level).

That the commercial expression issue remains volatile, and judicial pronouncements on the subject unpredictable, is highlighted by reviewing the recent words of one of the more "popular" commentators on Charter decisions. After the Ford decision, but prior to the Irwin Toy decision, Professor Allan 
Hutchinson ${ }^{|S|}$ lamented the granting of constitutional protection to commercial speech and issued dire warnings that in future, in areas like children's advertising "where proof cannot be scientific and the issue is as much about values as empirical evidence, any doubts will be resolved (by the courts) in favour of the commercial interests." 152 When the Irwin Toy decision was handed down, with the majority deciding in favour of the public interest, rather than the commercial interest, the same author, without expressing any surprise, gave the decision a begrudging "one cheer". ${ }^{153}$ What a Supreme Court of Canada of a different composition will do with the issue, however, must remain, for the time being, a matter of conjecture. ${ }^{154}$

151. A.C. Hutchinson, "'Opening Pandora's box. Advertising has been given constitutional protection: it shouldn't have," The Globe and Mail, (9 May 1989).

152. Ibid.

153. A.C. Hutchinson, "Long-term implications of Inwin Toy a concern," The Lawyer's Weekly, (30 June 1989) at 4.

154. On going to press, it is noted that the B.C. Court of Appeal's decision in Griffin v. College of Dental Surgeons of B.C. has been reported [1990] 1 W.W.R. 503. The Court recognized that, in view of the Supreme Court of Canada's decision in Ford and /nwin Toy, the conclusion of Madam Justice Rowles in Chambers that section 2(b) does not protect the right to advertise was wrong. A majority of the B.C. appellate court, however, upheld, under section 1 , the regulation restricting the rights of dentists to advertise, holding that such regulation is important in the preservation of professionalism and the maintenance of an appropriate standard of competency and ethics. The decision, of course, is directly opposite to that reached by the Ontario Court of Appeal in Rocket. Clearly this current "impasse" on the issue of advertising by the professions means that the Supreme Court of Canada's judgement on the appeal in the Rocket case cannot come too soon. 